Model Pengembangan Kurikulum Adaptif pada Madrasah Ibtidaiyah....

\title{
MODEL PENGEMBANGAN KURIKULUM ADAPTIF \\ PADA MADRASAH IBTIDAIYAH INKLUSIF
}

\author{
Nur Jannah ${ }^{1}$ \\ Syarifatul Marwiyah ${ }^{2}$ \\ IAI Al-Falah As-sunniyyah Kencong \\ (nurjannah.2583@gmail.com)
}

\begin{abstract}
The existence of a special school as one of the educational institutions, which is specifically intended to educate children with special needs in reality still cannot fully accommodate the education of children with special needs. The increasing number of children with special needs while the existence of special schools is limited in each district in Indonesia that has caused many parents to send their children with special needs to formal education institutions, one of them is madrasah. This phenomenon requires madrasah to adjust to their presence by becoming an institution that is friendly and inclusive of students whatever the conditions. One such effort is to develop an inclusive madrasah curriculum, a curriculum that is suitable for the needs of children with special needs. The following article discusses the Adaptive Curriculum Development Model with a focus on discussion on inclusive madrasah ibtidaiyah with the aim of developing an adaptive curriculum in which there are models of duplication, modification, substance and omission. All models of curriculum development can be an option to be implemented in an inclusive Madrasah Ibtidaiyah, depending on which model is considered as the most appropriate for the conditions of students in madrasah and which is possible to apply, this is because each madrasah has different conditions between one and the other, so they can implement a curriculum model that suits their students' needs.
\end{abstract}

Keywords: special school, madrasah ibtidaiyah, inclusive, curriculum

\begin{abstract}
Abstrak
Eksistensi sekolah luar biasa sebagai salah satu lembaga pendidikan yang diperuntukkan khusus mendidik anak-anak berkebutuhan khusus pada realitasnya masih belum bisa sepenuhnya menampung pendidikan anak berkebutuhan khusus. Bertambahnya jumlah anak berkebutuhan khusus sementara keberadaan sekolah luar biasa terbatas ditiap-tiap kabupaten di Indonesia menyebabkan banyak orang tua menyekolahkan anaknya yang berkebutuhan khusus di lembaga pendidikan formal, salah satunya di madrasah. Fenomena
\end{abstract}

\footnotetext{
${ }^{1}$ Dosen IAI Al-Falah As-Sunniyyah Kencong-Jember

${ }^{2}$ Dosen IAI Al-Falah As-Sunniyyah Kencong-Jember
} 
Nur Jannah

\section{Syarifatul Marwiyah}

tersebut menuntut madrasah menyesuaikan diri atas kehadiran mereka dengan menjadi lembaga yang ramah dan inklusif terhadap peserta didik apapun kondisinya. Salah satu upaya tersebut adalah dengan mengembangkan kurikulum madrasah inklusif, yakni kurikulum yang sesuai dengan kebutuhan anak-anak berkebutuhan khusus. Artikel berikut membahas tentang Model Pengembangan Kurikulum Adaptif dengan fokus pembahasan pada madrasah ibtidaiyah inklusif bertujuan untuk mengembangkan kurikulum adaptif yang didalamnya terdapat model duplikasi, modifikasi, substansi dan omisi. Semua model pengembangan kurikulum ini bisa menjadi salah satu pilihan untuk diimplementasikan pada madrasah ibtidaiyah inklusif, tergantung model manakah yang dianggap paling sesuai dengan kondisi siswa di madrasah dan yang memungkinkan untuk diterapkan, hal ini dikarenakan setiap madrasah mempunyai kondisi yang berbeda antara satu dan yang lainnya, sehingga mereka bisa mengimplementasikan model kurikulum yang sesuai dengan kebutuhan peserta didiknya.

Kata Kunci: sekolah luar biasa, madrasah ibtidaiyah, inklusif, kurikulum

\section{PENDAHULUAN}

Pengembangan kurikulum di Madrasah pada umumnya sudah dilakukan dengan cukup baik dan beragam, hanya saja dengan banyaknya peserta didik berkebutuhan khusus yang ingin mengenyam pendidikan di Madrasah maka perlu dikembangkan lagi kurikulum yang ada di Madrasah sesuai dengan kebutuhan anak berkebutuhan khusus tersebut. Adanya peserta didik yang bersekolah di Madrasah ini dapat membuka peluang bagi madrasah sebagai salah satu lembaga pendidikan Islam yang berperan aktif untuk mencerdaskan kehidupan bangsa dengan mendidik anak-anak berkebutuhan khususi mulai dari jenjang Madrasah Ibtidaiyah hingga Madrasah Aliyah, sehingga anak-anak berkebutuhan khusus tersebut dapat memperoleh kesempatan belajar yang sama dengan anak-anak pada umumnya terutama mempelajari nilai-nilai Islam yang diajarkan di Madrasah sebagai bekal kehidupan di masa depannya.

Untuk menjadi lembaga pendidikan yang berlabel inklusi ini tentunya tidak mudah bagi Madrasah karena membutuhkan kesiapan berbagai macam pihak terutama guru yang kompeten untuk mendidik anak berkebutuhan khusus mengingat mendidik anak berkebutuhan khusus ini bukanlah hal yang mudah karena membutuhkan kesabaran ekstra para guru dalam mendidik anak berkebutuhan khusus ini tentu berbeda dengan anak-anak normal, selain itu juga dibutuhkan kurikulum yang sesuai dengan kebutuhan anak berkebutuhan khusus, sarana dan prasarana yang memadai.

90| Jurnal Auladuna 
Model Pengembangan Kurikulum Adaptif pada Madrasah Ibtidaiyah....

Eksistensi Madrasah inklusi ini sebenarnya dalam rangka ikut memberikan solusi pendidikan bagi anak-anak berkebutuhan khusus yang tidak bisa bersekolah di sekolah luar biasa karena rata-rata jarak sekolah luar biasa yang jauh bahkan sulit dijangkau oleh anak berkebutuhan khusus. Keberadaan sekolah luar biasa yang tidak terlalu banyak sementara jumlah anak berkebutuhan khusus ini yang terus bertambah, hal ini bisa kita lihat berdasarkan data terakhir BPS pada tahun 2017 jumlah anak berkebutuhan khusus di negeri ini mencapai angka 1,6 juta anak, dan sebagian besar mereka belum memperoleh pendidikan yang layak. Untuk menyelesaikan persoalan pendidikan bagi anak berkebutuhan khusus maka pemerintah melalui kemendikbud melakukan salah satu upaya untuk memberikan akses pendidikan kepada mereka melalui pembangunan unit baru Sekolah Luar Biasa dan juga mendorong tumbuhnya sekolah inklusi di daerah-daerah minimal disetiap zonasi ada satu lembaga pendidikan inklusi.

Dengan adanya kebijakan yang dibuat pemerintah itu sebenarnya dapat memberikan kesempatan besar kepada Madrasah-madrasah di seluruh Indonesia untuk ikut membantu memberikan layanan pendidikan bagi anak berkebutuhan khusus, sehingga anak-anak berkebutuhan khusus ini bisa dengan mudah memperoleh pendidikan seperti halnya anak normal lainnya, karena pada dasarnya anak-anak berkebutuhan khusus ini juga berhak mendapatkan kesempatan belajar yang sama seperti anak-anak yang lainnya.

Uraian di atas tersebut sesuai dengan salah satu cita-cita kemerdekaan bangsa Indonesia yaitu mencerdaskan kehidupan bangsa, dan untuk mencapai cita-cita bangsa tersebut dapat dilakukan diantaranya melalui pendidikan yang bermutu. Hal itu sesuai dengan UUD 1945 Pasal 31 ayat (1) menjelaskan bahwa "Setiap warga Negara berhak mendapatkan pendidikan", dari pasal tersebut dapat kita pahami bahwa pendidikan itu berhak diperoleh untuk semua warga Negara tanpa ada pengecualian sama sekali, baik itu yang sehat secara fisik maupun yang memiliki kelainan fisik, emosional, mental dan social, serta dimanapun mereka tinggal tetap harus mendapatkan pendidikan. karena pendidikan merupakan suatu kebutuhan bagi setiap insan, dan dengan pendidikan manusia mempunyai harapan untuk dapat melanjutkan kehidupan sesuai dengan tantangan zaman, oleh karena itu pendidikan harus mudah dijangkau semua masyarakat dengan berbagai macam kondisi. 
Nur Jannah

Syarifatul Marwiyah

Dalam Undang-Undang Sisdiknas pada Bab IV tentang Hak dan Kewajiban Warga Negara pada pasal 5 ayat (1-4) juga menjelaskan tentang "setiap warga Negara mempunyai hak dan kewajiban yang sama untuk memperoleh pendidikan yang bermutu. Warga Negara yang memiliki kelainan fisik, emosional, mental, intelektual, dan/atau sosial berhak memperoleh pendidikan khusus. Warga Negara di daerah terpencil atau terbelakang serta masyarakat adat yang terpencil berhak memperoleh pendidikan layanan khusus. Warga Negara yang memiliki potensi kecerdasan dan bakat istimewa berhak memperoleh pendidikan khusus. ${ }^{3}$

Berdasarkan beberapa penjelasan payung hukum di atas menunjukkan bahwa pendidikan dapat diselenggarakan dengan menghargai berbagai macam perbedaan, keanekaragaman, dan dapat melayani berbagai macam kebutuhan peserta didik tanpa adanya perbedaan sedikitpun, termasuk untuk anak berkebutuhan khusus. Hal ini tentu dapat membawa angin segar bagi orangtua yang memiliki anak berkebutuhan khusus karena mereka tidak harus menyekolahkan putra-putrinya di Sekolah Luar Biasa saja tetapi juga bisa menyekolahkan anaknya di sekolah-sekolah inklusi. Hal tersebut sudah dijelaskan dalam Undang-undang No 20 Tahun 2003 Pasal 5 tentang pendidikan khusus, bahwa pendidikan khusus merupakan pendidikan untuk peserta didik yang berkelainan atau peserta didik dengan kecerdasan luar biasa dan di selenggarakan secara inklusi.

Selain aturan di atas ada juga aturan lain tentang pendidikan anak berkebutuhan khusus yang tertuang dalam permendiknas No. 70 Tahun 2009 yang berbunyi bahwa telah diberikan kesempatan kepada anak berkebutuhan khusus untuk mengenyam pendidikan di sekolah regular pada tingkat sekolah dasar hingga sekolah menengah. Dengan adanya aturan-aturan terkait pendidikan anak berkebutuhan khusus, maka akan sangat membantu dan memudahkan anak berkebutuhan khusus untuk mendapatkan pendidikan, terlebih lagi jika banyak Madrasah-madrasah yang siap menerima peserta didik yang berkebutuhan khusus, untuk itu perlu adanya upaya keras madrasah agar layak menjadi salah satu lembaga yang ikut berkontribusi mencerdaskan anak-anak berkebutuhan khusus ini.

Dalam dunia internasional juga telah terjadi sebuah kesepakatan mengenai pendidikan inklusi, yang tertuang dalam Conventional on the Right of Person with

${ }^{3}$ Peraturan Menteri Pendidikan Nasional Nomor 70 Tahun 2009 Tentang Pendidikan Inklusif bagi Peserta Didik yang Memiliki Kelainan dan Memiliki Potensi Kecerdasan dan/ atau Bakat Istimewa. Jakarta: Direktorat Jenderal Pendidikan Dasar.

92 | لurnal Auladuna 
Model Pengembangan Kurikulum Adaptif pada Madrasah Ibtidaiyah.... Disabilities and Optional Protocol yang disahkan pada bulan Maret 2007. Hal tersebut tertuang dalam pasal 24, yang berbunyi setiap negara wajib menyelenggarakan pendidikan inklusi disetiap tingkat pendidikan. Tujuan yang mendasari terbentuknya konvensi ini adalah agar anak berkebutuhan khusus dapat berpartisipasi dalam kehidupan masyarakat umum. ${ }^{4}$

Dengan realitas yang ada maka perlu adanya pengembangan kurikulum Madrasah Ibtidaiyah Inklusif bagi Madrasah-madrasah yang menerima peserta didik berkebutuhan khusus, agar kurikulum yang digunakan untuk mendidik anak berkebutuhan khusus ini sesuai dengan kebutuhan peserta didik, mengingat banyak macamnya pembagian anak berkebutuhan khusus maka kurikulum yang digunakan harus dirubah sedemikian rupa sesuai dengan kebutuhan peserta didiknya.

Tulisan ini mencoba untuk membahas tentang model pengembangan kurikulum adaftif di Madrasah Ibtidaiyah Inklusif. Dimana pada umumnya kurikulum Madrasah menggunakan kurikulum 2013, dan hanya menerima siswa yang normal saja, akan tetapi pada Madrasah Ibtidaiyah Inklusif menerima siswa anak berkebutuhan khusus, sehingga kurikulum yang ada harus dikembangkan menjadi kurikulum adaptif agar sesuai dengan kondisi peserta didik yang ada.

\section{PEMBAHASAN}

\section{Madrasah Ibtidaiyah Inklusif}

Kata Madrasah tentu bukan kata yang asing di masyarakat kita, namun untuk menyamakan persepsi perlu kita pahami apa maksud dari madrasah itu sendiri. Kata Madrasah itu berasal dari bahasa Arab yang artinya sekolah, secara bahasa madrasah berasal dari kata "darosa" yang artinya belajar, sedangkan secara istilah Madrasah dapat diartikan sebagai lembaga pendidikan bernuansa Islam yang berada di bawah naungan Kementerian Agama dimana terdapat beberapa satuan pendidikan formal mulai dari Raudhatul Athfal, Madrasah Ibtidaiyah, Madrasah Tsanawiyah, Madrasah Aliyah dan Madrasah Aliyah Kejuruan. ${ }^{5}$ Lembaga pendidikan Madrasah ini memiliki penekanan

\footnotetext{
${ }^{4}$ N. Praptiningrum, Fenomena Penyelenggaraan Pendidikan Inklusif bagi Anak Berkebutuhan, Jurnal Pendidikan Khusus Vol. 7 No. 2 (2010), 32-39

${ }^{5}$ Peraturan Menteri Agama Republik Indonesia No. 90 Th. 2013.
} 
Nur Jannah

\section{Syarifatul Marwiyah}

sebagai suatu lembaga yang mengajarkan ilmu-ilmu tentang keislaman. ${ }^{6}$ Hal ini tentu berbeda dengan lembaga pendidikan umum yang justru lebih banyak mengajarkan ilmu pengetahuan umum dari pada pendidikan agama.

Dari pengertian Madrasah di atas dapat dipahami maksud dari Madrasah Ibtidaiyah adalah satuan pendidikan formal yang menyelenggarakan pendidikan umum dengan agama Islam yang menjadi ciri khasnya dan terdiri dari 6 tingkatan pada jenjang pendidikan dasar. ${ }^{7}$ Madrasah Ibtidaiyah merupakan salah satu lembaga pendidikan dasar Islam yang lebih modern, yang memadukan antara pendidikan pesantren dan sekolah, dimana materinya mengintegrasikan agama juga pengetahuan umum. Madrasah sebagai lembaga pendidikan Islam berfungsi menghubungkan sistem lama dan sistem baru dengan jalan mempertahankan nilai-nilai lama yang masih baik dan dapat dipertahankan dan mengambil sesuatu yang baru dalam ilmu, tekhnologi dan ekonomi yang bermanfaat bagi kehidupan umat Islam, sedangkan isi kurikulum yang madrasah pada umumnya sama dengan pendidikan di pesantren yang ditambahi dengan ilmu-ilmu umum. ${ }^{8}$

Tujuan Penerapan pendidikan inklusi di Madrasah Ibtidaiyah ini agar dapat memberikan layanan pendidikan dasar bagi anak-anak berkebutuhan khusus. Munculnya konsep pendidikan inklusi ini dimaksudkan untuk memberikan solusi, terhadap adanya perlakuan diskriminatif dalam layanan pendidikan terutama bagi anak-anak berkebutuhan khusus, pendidikan inklusi memiliki prinsip dasar bahwa selama memungkinkan seyogyanya anak bisa belajar bersama-sama tanpa memandang kesulitan ataupun perbedaan yang mungkin adapada mereka. ${ }^{9}$

Sedangkan Madrasah Ibtidaiyah Inklusif disini berbeda dengan madrasah Ibtidaiyah pada umumnya, karena madrasah Ibtidaiyah Inklusif disini menerima anak berkebutuhan khusus sebagai peserta didik yang akan belajar bersama dengan anak-anak normal lainnya, sehingga dalam proses menyelenggarakan pendidikan tidak ada perbedaan bagi peserta didik anak berkebutuhan khusus dan anak normal lainnya.

\footnotetext{
${ }^{6}$ Haidar Putra Daulay. Sejarah Pertumbuhan dan Pembaharuan Pendidikan Islam Indonesia (Jakarta: Kencana Predana Media Group, 2009), 94

${ }^{7}$ Peraturan Menteri Agama Republik Indonesia No. 90 Th. 2013.

${ }^{8}$ Haedar Nashir, Pendidikan Karakter Berbasis Agama (Yogyakarta: Multi Presindo, 2013), 27

${ }^{9}$ J. David Smith, Inklusi, Sekolah Ramah untuk Semua, terj. Denis. Bandung: Penerbit Nuansa, 2006), 26 94 | لurnal Auladuna
} 
Model Pengembangan Kurikulum Adaptif pada Madrasah Ibtidaiyah....

Di Indonesia sendiri eksistensi Madrasah Ibtidaiyah sangat banyak sekali dan tidak diragukan lagi sebagai salah satu lembaga yang ikut berperan dalam mencerdaskan kehidupan bangsa hanya saja Madrasah Ibtidaiyah yang berlabel Inklusi masih jarang sekali di temukan, mengingat kurangnya kesiapan Madrasah untuk menjadi lembaga pendidikan inklusi. Sekolah inklusi di sini bukanlah sekolah luar biasa yang mengekslusifkan peserta didiknya, akan tetapi sekolah regular yang juga menerima peserta didik berkebutuhan khusus untuk belajar bersama dengan peserta didik yang normal. ${ }^{10}$ Model sekolah seperti ini mempunyai tujuan untuk memberikan kesempatan bagi semua anak berkebutuhan khusus untuk belajar dan mendapatkan pendidikan yang berkualitas yang sesuai dengan kebutuhan dan kompetensinya.

\section{Model Pengembangan Kurikulum Adadtif}

Dalam dunia pendidikan istilah kurikulum tentu sudah seringkali kita dengar, namun sebelum kita membahas tentang model pengembangan kurikulum Madrasah Ibtidaiyah inklusif terlebih dahulu kita bakan membahas tentang maksud kurikulum itu sendiri agar terdapat kesamaan dalam memahami pengertian kurikulum secara komprehensif. Dalam bahasa latin kata kurikulum berati a running course, or race course, especialli a chariot race course. Kurikulum secara tradisional juga dapat diartikan sebagai mata pelajaran yang diajarkan di sekolah. ${ }^{11}$ Lazimnya kurikulum dipandang sebagai suatu rencana yang disusun untuk melancarkan proses belajar mengajar di bawah bimbingan dan tanggung jawab sekolah atau lembaga pendidikan beserta staf pengajarnya. ${ }^{12}$

Istilah kurikulum sendiri dalam bahasa Arab diartikan dengan kata manhaj, yakni jalan yang terang, atau jalan terang yang dilalui oleh manusia pada bidang kehidupannya. Kurikulum dalam konteks pendidikan berarti jalan terang yang dilalui oleh seorang pendidik dengan peserta didik untuk mengembangkan pengetahuan, ketrampilan dan juga sikap serta nilai-nilai. Pendapat lain menjelaskan al-manhaj sebagai seperangkat rencana dan media untuk mengantarkan lembaga pendidikan dalam mewujudkan tujuan pendidikan

\footnotetext{
${ }^{10}$ Ishartiwi, Implementasi Pendidikan Inklusif bagi Anak Berkebutuhan Khusus dalam Sistem Persekolahan Nasional, Jurnal Pendidikan Vol. 6 No. 2. (2006)

${ }^{11}$ Handani Ihsan dan Fuad Ihsan, Filsafat Pendidikan Islam (Bandung: Pustaka Setia, 2001), 131

${ }^{12}$ Helmut Nolker dan Eberhard Schoenfeldt, Berufsbildung, Unterricht, Curriculum, Planning, Terj. Agus Setiadi (Jakarta: PT. Gramedia, 1983), 74-75
} 
Nur Jannah

\section{Syarifatul Marwiyah}

yang diinginkan. ${ }^{13}$ Dalam UU Sisdiknas Nomor 20/2003 definisi kurikulum dikembangkan ke arah seperangkat rencana dan pengaturan mengenai tujuan, isi dan bahan pelajaran serta cara yang digunakan sebagai pedoman penyelenggaraan kegiatan pembelajaran untuk mencapai tujuan pendidikan tertentu. Dengan demikian ada tiga komponen yang termuat dalam kurikulum, yaitu tujuan, isi dan bahan pelajaran serta cara pembelajaran, baik yang berupa strategi pembelajaran maupun evaluasinya. ${ }^{14}$

Kurikulum dimaksudkan untuk menunjukkan pada usaha-usaha yang mengarah pada tujuan pendidikan atau tujuan sekolah. ${ }^{15}$ Sementara pendapat lain menjelaskan bahwa kurikulum merupakan sejumlah pengalaman pendidikan, kebudayaan, sosial, olah raga, kesenian baik yang berada di dalam maupun di luar kelas yang dikelola oleh sekolah. ${ }^{16}$ Pandangan lain tentang kurikulum adalah melihat kurikulum sebagai program pendidikan, yakni program belajar bagi peserta didik atau plan for learning. Kurikulum sebagai program belajar bagi peserta didik, disusun secara sistematis dan logis, diberikan oleh sekolah untuk mencapai tujuan pendidikan. Sebagai program belajar, kurikulum adalah niat, rencana dan harapan. ${ }^{17}$

Kurikulum dapat dianalogikan dengan suatu organisme misalnya saja manusia, yang memiliki susunan anatomi tertentu. Komponen-komponen dari anatomi tubuh kurikulum yaitu, tujuan, materi atau disebut juga isi, proses, dan evaluasi. ${ }^{18}$ Keempat komponen tersebut saling berhubungan satu sama lain, setiap komponennya bertalian erat dengan ketiga komponen lainnya. Apabila salah satu komponennya berubah, misalnya ditonjolkannya tujuan yang baru, atau proses belajar mengajar, misalnya menggunakan metode baru, atau cara penilaian, maka semua komponen lainnya turut mengalami perubahan. $^{19}$

Hal tersebut sejalan dengan pendapat Hamalik yang menyatakan bahwa kurikulum terbentuk oleh empat komponen yaitu, komponen tujuan, isi kurikulum, metode atau

\footnotetext{
${ }^{13}$ Muhaimin, Pengembangan Kurikulum Pendidikan Agama Islam di Sekolah, Madrasah dan Perguruan Tinggi (Jakarta: PT. Grafindo Persada, 2010), 1

${ }^{14}$ Undang-undang Sistem Pendidikan Nasional Republik Indonesia No. 2 Th. 2003 (Jakarta: Sinar Grafika)

${ }^{15}$ Nurdin Syafruddin, Guru Profesional dan Implementasi Kurikulum (Jakarta: Ciputat Pers, 2002), 34

${ }^{16}$ Abuddin Nata, Filsafat Pendidikan Islam (Jakarta: Logos Wacana Ilmu, 1997), 124

17 Arief Lewy, Planning the School Curriculum, terj. Winda Habimono (Jakarta: Bhratara Karya Aksara, 1983), 1

18 Nana Syaodih Sukmadinata, Pengembangan Kurikulum: Teori dan Praktek (Bandung: PT Remaja Rosdakarya, 2005), 102

${ }^{19}$ Nasution, Asas-Asas Kurikulum (Jakarta: PT Bumi Aksara, 2001), 18

96 | Jurnal Auladuna
} 
Model Pengembangan Kurikulum Adaptif pada Madrasah Ibtidaiyah.... strategi pencapaian tujuan dan komponen evaluasi. Sebagai suatu sistem, setiap komponen harus saling berkaitan satu sama lain, manakala salah satu komponen yang terbentuk sistem kurikulum terganggu atau tidak berkaitan dengan komponen lainnya maka sistem kurikulum juga akan terganggu. Dalam kurikulum pendidikan inklusi komponen kurikum pada umumnya sama dengan kurikulum reguler lainnya. ${ }^{20}$

Dalam dunia pendidikan kurikulum merupakan sesuatu yang terus berkembang sesuai dengan perkembangan zaman dan kebutuhan peserta didik. Pengembangan kurikulum sendiri merupakan perencanaan kesempatan-kesempatan belajar yang dimaksudkan untuk membawa siswa ke arah perubahan-perubahan yang diinginkan dan menilai hingga mana perubahan-perubahan itu telah terjadi pada diri siswa. Sedangkan yang dimaksud kesempatan belajar adalah hubungan yang telah direncanakan dan terkontrol antara para siswa, guru, bahan peralatan, dan lingkungan dimana belajar yang diinginkan diharapkan terjadi. $^{21}$

Suatu kurikulum harus mempunyai kesesuaian atau relevansi, kesesuaian ini meliputi dua hal penting. Pertama kesesuaian kurikulum dengan tuntutan, kebutuhan, kondisi dan perkembangan masyarakat. Kedua kesesuaian antar komponen-komponen kurikulum, yaitu isi sesuai dengan tujuan, proses dengan isi tujuan, begitu juga evaluasi juga harus sesuai dengan proses, isi, dan tujuan kurikulum. ${ }^{22}$ Salah satu indicator berhasil atau tidaknya pendidikan ini terletak pada kurikulum yang digunakan, oleh karena itu perlu adanya pengembangan kurikulum. Pengembangan kurikulum sendiri merupakan proses perencanaan kurikulum agar menghasilkan rencana kurikulum yang luas dan spesifik. ${ }^{23}$

Sedangkan menurut Muhaimin pengembangan kurikulum dapat diartikan sebagai suatu kegiatan penyusunan, pelaksanaan, penilaian dan penyempurnaan kurikulum. ${ }^{24}$ Dengan kata lain pengembangan kurikulum dapat dikatakan dengan istilah yang menyeluruh yang didalamnya mencakup perencanaan, penerapan dan evaluasi. Perencanaan disini merupakan langkah awal membangun kurikulum ketika pihak-pihak

\footnotetext{
${ }^{20}$ Oemar Hamalik, Dasar-dasar Pengembangan Kurikulum (Bandung: PT Remaja Rosdakarya, 2007), 9

${ }^{21}$ Oemar Hamalik. Manajemen Pengembangan Kurikulum (Bandung: PT Remaja Rosdakarya, 2006), 97

${ }^{22}$ Ibid.,

${ }^{23}$ Dyah. S., Pengkajian Pendidikan Inklusif bagi Anak Berkebutuhan Khusus pada Jenjang Pendidikan Dasar dan Menengah (Jakarta: Depdiknas, 2008)

${ }^{24}$ Muhaimin. Pengembangan Kurikulum Pendidikan Agama Islam: di Sekolah, Madrasah, dan Perguruan Tinggi (2010)
} 
Nur Jannah

\section{Syarifatul Marwiyah}

terkait membuat keputusan dan mengambil tindakan untuk menghasilkan perencanaan yang akan digunakan oleh guru dan anak, sedangkan implementasi kurikulum itu berusaha mentransfer perencanaan kurikulum ke dalam suatu tindakan operasional. Tahap akhir pada pengembangan kurikulum adalah evaluasi kurikulum yang dilakukan untuk menentukan seberapa besar hasil-hasil pembelajaran, tingkat ketercapaian program-program yang telah direncanakan, dan hasil-hasil kurikulum yang telah diterapkan. ${ }^{25}$

Dalam pengembangan kurikulum ada beberapa prinsip umum yang perlu diperhatikan yaitu relevansi, fleksibilitas, kontinuitas, praktis dan efektivitas. ${ }^{26}$ Selain itu untuk mengembangkan kurikulum memerlukan partisipasi beberapa pihak, misalnya administrator pendidikan, ahli pendidikan, ahli kurikulum, ahli bidang ilmu pengetahuan, guru-guru, orang tua murid dan tokoh-tokoh masyarakat. ${ }^{27}$ Dari penjelasan di atas, maka dapat diambil sebuah benang merah bahwa pengembangan kurikulum Madrasah Inklusif adalah penyusunan kurikulum sesuai dengan standar nasional pendidikan yang dapat mengakomodasi potensi, bakat, minat, kompetensi, kemampuan dan kebutuhan peserta didik.

Tujuan pengembangan kurikulum pada pendidikan inklusi, pertama, untuk membantu peserta didik dalam mengembangkan potensi dan mengatasi hambatan belajar yang dialami peserta didik semaksimal mungkin dalam setting sekolah inklusi. Kedua, membantu guru dan orang tua dalam mengembangkan program pendidikan bagi peserta didik berkebutuhan khusus baik yang diselenggarakan di sekolah, di luar sekolah, maupun di rumah. Ketiga, menjadi pedoman bagi sekolah dan masyarakat dalam mengembangkan menilai dan menyempurnakan program pendidikan inklusi. ${ }^{28}$

Pada dasarnya kurikulum Madrasah Ibtidaiyah inklusif ini menggunakan kurikulum 13 seperti halnya yang digunakan disekolah umum lainnya, hanya saja berhubung di Madrasah Ibtidaiyah Inklusif itu mempunyai peserta didik yang memiliki berbagai macam karakteristik dari yang normal hingga berkebutuhan khusus dengan bermacam-macam hambatan, oleh karena itu dalam penerapan kurikulum perlu adanya penyesuaian yang

25 Unesco, Pendidikan Kebutuhan Khusus, terj. Susi Septaviana Rakhmawati (Oslo: Unifub Forlag Universitas Oslo, 2001)

${ }^{26}$ Nana Syaodih Sukmadinata, Pengembangan Kurikulum: Teori dan Praktek (Bandung: PT Remaja Rosdakarya, 2005), 150-151

${ }^{27}$ Ibid., 155

${ }^{28}$ R. Indianto. Implementasi Pendidikan Inklusi (Surakarta: Universitas Sebelas Maret, 2013), 16 98| Jurnal Auladuna 
Model Pengembangan Kurikulum Adaptif pada Madrasah Ibtidaiyah.... sedemikian rupa sehingga meskipun mempunyai peserta didik yang beragam kurikulum tersebut sesuai dengan kebutuhan zaman dari peserta didik tersebut.

Kebutuhan perencanaan pengalaman belajar melalui kurikulum yang disesuaikan adalah conditio sine qua non dalam memberikan pengalaman pendidikan bagi anak berkebutuhan khusus, meskipun kurikulum umum yang komprehensif sebagian bisa juga digunakan untuk melayani anak berkebutuhan khusus, namun ada kebutuhan-kebutuhan tertentu yang tidak dapat diperolehnya melalui melalui pembelajaran biasa sebagaimana dilaksanakan bagi anak normal pada umumnya. ${ }^{29}$

Pendidikan anak berkebutuhan khusus di sekolah inklusi dapat dilakukan dengan berbagai macam model sebagai berikut: ${ }^{30}$

1. Kelas Reguler (inklusi penuh); anak berkebutuhan khusus belajar bersama anak non berkebutuhan khusus sepanjang hari di kelas reguler dengan menggunakan kurikulum yang sama.

2. Kelas Reguler dengan Cluster; anak berkebutuhan khusus belajar bersama anak non berkebutuhan khusus di kelas reguler dalam kelompok khusus.

3. Kelas Reguler dengan Pull Out; anak berkebutuhan khusus belajar dengan anak non berkebutuhan khusus di kelas reguler, namun dalam waktu-waktu tertentu ditarik dari kelas reguler ke ruang lain untuk belajar dengan pembimbing khusus.

4. Kelas reguler dengan Cluster dan Pull Out; anak berkebutuhan khusus belajar bersama anak non berkebutuhan khusus di kelas reguler dalam kelompok khusus, dan dalam waktu-waktu tertentu ditarik dari kelas reguler ke ruang lain untuk belajar dengan guru pembimbing khusus.

5. Kelas Khusus dengan Berbagai Pengintegrasian; anak berkebutuhan khusus belajar di dalam kelas khusus pada sekolah reguler, namun dalam bidang-bidang tertentu dapat belajar bersama anak non berkebutuhan khusus dikelas reguler.

Selain model di atas, ada juga model pengembangan kurikulum adaptif dimana kurikulumnya sudah dimodifikasi dan diadaptasi sedemikian rupa disesuaikan dengan kebutuhan dan juga kondisi kemampuan serta keterbatasan anak berkebutuhan khusus sehingga dapat memudahkan mereka dalam mengikuti kegiatan belajar di Madrasah

${ }^{29}$ Cony Semiawan, Perspektif Pendidikan Anak Berbakat (Jakarta: Grasindo, 1997), 25

${ }^{30}$ Emawati, Mengenal Lebih Jauh Sekolah Inklusi, Pedagogik Jurnal Pendidikan Vol. 5 No. 1 (2008), 25-35 
Nur Jannah

\section{Syarifatul Marwiyah}

Inklusi. Berikut ini ada beberapa model kurikulum adaptif yang dapat diimplementasikan pada sekolah-sekolah inklusi:

\section{Model Duplikasi}

Model kurikulum ini pada dasarnya sama dengan kurikulum yang digunakan pada anak normal pada umumnya di sekolah reguler. Model kurikulum ini diterapkan pada empat komponen yang meliputi tujuan, isi, proses, dan evaluasi. Kelebihan model kurikulum ini yaitu peserta didik yang berkebutuhan khusus akan mendapatkan kurikulum yang sama dengan anak-anak normal lainnya, artinya tidak ada perbedaan kurikulum yang digunakan. Sementara kekurangan dari model kurikulum ini kurang dapat mengakomodasi kebutuhan peserta didik yang berkebutuhan khusus karena pada dasarnya mereka ini sangat beragam jenis dan kemampuannya sehingga tidak dapat disamakan dengan anak normal lainnya.

\section{Model Modifikasi}

Model kurikulum ini merupakan pengembangan kurikulum 2013 yang diberlakukan pada siswa yang normal lalu disesuaikan dengan kemampuan anak berkebutuhan khusus. Modifikasi pada kurikulum ini dapat dilakukan pada empat komponen, yaitu: Modifikasi tujuan, modifikasi isi atau materi, modifikasi proses dan modifikasi evaluasi. Modifikasi ini dapat dilakukan pada satu atau semua komponen, misalnya modifikasi hanya dilakukan pada proses pembelajarannya saja sedangkan ketiga komponen yang lain tetap tidak dimodifikasi. Hal ini tergantung pada kondisi peserta didik yang ada, jadi model kurikulum ini sangat fleksibel menyesuaikan bagaimana peserta didiknya. Kelebihan kurikulum ini akan lebih mengakomodasi kekurangan dari peserta didik berkebutuhan khusus yang sangat beragam.

\section{Model Substansi}

Model substansi ini mengembangkan kurikulum dengan mengganti sesuatu yang ada dalam kurikulum umum dengan sesuatu yang lain. Penggantian ini dilakukan dengan mengganti kurikulum yang umum dengan kurikulum baru yang kurang lebih sepadan dengan kurikulum yang diberlakukan pada siswa normal, karena kurikulum tersebut tidak mungkin diterapkan pada anak berkebutuhan khusus. Pengembangan model ini juga dapat diberlakukan pada empat komponen yaitu tujuan, materi, proses 
Model Pengembangan Kurikulum Adaptif pada Madrasah Ibtidaiyah.... dan evaluasinya. Kelebihan model ini justru lebih fleksibel sesuai dengan kebutuhan pembelajaran bagi anak berkebutuhan khusus.

\section{Model Omisi}

Model ini dapat dilakukan dengan cara menghilangkan sebagian atau keseluruhan kurikulum umum yang berlaku, hal ini dilakukan karena kurikulum um um ini tidak mungkin bisa diterapkan pada peserta didik berkebutuhan khusus. Jadi apa yang diterapkan pada kurikulum umum ini tidak diterapkan pada siswa yang berkebutuhan khusus karena dianggap sulit dan tidak sesuai dengan kebutuhan siswa. ${ }^{31}$

Dari ke empat model kurikulum di atas dan ke empat komponen utama kurikulum yaitu tujuan, materi, proses dan evaluasi, dapat diterapkan di Madrasah Ibtidaiyah Inklusif dengan mengawinkan atau memadukan antara model kurikulum dan komponen kurikulum tersebut, sehingga akan muncul berbagai macam kemungkinan perpaduan-perpaduan yang sesuai dengan kondisi masing-masing peserta didik di Madrasah, oleh karena itu apapun model kurikulum yang diterapkan harus fleksibel menyesuaikan kebutuhan dan bagaimana kondisi peserta didiknya, sehingga anak berkebutuhan khusus ini dapat mendapatkan layanan pendidikan berkualitas yang sesuai dengan bakat, minat dan kompetensinya, selain itu hal penting yang harus diperhatikan dalam menyelenggarakan pendidikan khusus adalah pendidik atau guru Madrasah Ibtidaiyah harus dapat melayani siswa dengan berbagai macam kebutuhan belajar ${ }^{32}$ dan juga harus mempunyai pengetahuan terkait anak berkebutuhan khusus agar dapat menangani semua problem yang terkait dengan anak berkebutuhan khusus.

Di samping itu dalam melaksanakan pendidikan inklusi di Madrasah Ibtidaiyah ada beberapa hal yang harus dilakukan, yaitu: ${ }^{33}$

1. Madrasah harus dapat mengkondisikan kelas menjadi kelas yang hangat, ramah, menerima keanekaragaman dan menghargai perbedaan dengan menerapkan kurikulum dan pembelajaran yang interaktif.

\footnotetext{
${ }^{31}$ Budiyanto, dkk, Modul Pelatihan Pendidikan Inklusif (Jakarta: Kementerian Pendidikan Nasional, 2010)

${ }^{32}$ Mumpuniarti, Pembelajaran Nilai Keberagaman dalam Pembentukan Karakter Siswa SD Inklusi, Jurnal Pendidikan Karakter (Yogyakarta: LPPMP UNY, 2011)

${ }^{33}$ Suyanto dan Mudjito, Masa Depan Pendidikan Inklusif (Jakarta: Kemendiknas, 2012), 39
} 
Nur Jannah

\section{Syarifatul Marwiyah}

2. Pendidik dituntut untuk bisa berkolaborasi dengan profesi atau dengan sumber daya manusia lain dalam perencanaan, pelaksanaan dan evaluasi.

3. Pendidik dituntut untuk melibatkan orangtua secara bermakna dalam proses pendidikan.

4. Kepala sekolah dan guru yang nantinya akan menjadi guru pembimbing khusus untuk anak berkebutuhan khusus harus mendapatkan pelatihan tentang cara mengajar di sekolah inklusi.

5. Guru pembimbing khusus ini harus mendapatkan pelatihan tekhnis untuk memfasilitasi anak berkebutuhan khusus.

6. Asesmen di sekolah dilakukan untuk memahami anak berkebutuhan khusus dan penanganan yang diperlukan.

7. Mengiidentifikasi hambatan terkait dengan kelainan fisik, sosial, dan masalah lainnya terhadap akses dan pembelajaran anak berkebutuhan khusus.

8. Melibatkan masyarakat dalam melakukan perencanaan dan monitoring, mutu pendidikan bagi semua anak.

Kurikulum yang digunakan dalam penyelenggaraan pendidikan inklusi pada dasarnya menggunakan kurkulum reguler yang berlaku di sekolah umum. Namun karena hambatan anak berkebutuhan khusus ini beragam dan sangat bervariasi, mulai dari yang ringan, sedang sampai yang berat, maka dalam penerapan kurikulum reguler perlu dilakukan modifikasi sedemikian rupa sehingga sehingga sesuai dengan kebutuhan peserta didik. ${ }^{34}$

\section{Hambatan-hambatan dalam Pengembangan Kurikulum Madrasah Inklusif}

Dalam pengembangan kurikulum tidak akan pernah lepas dengan adanya hambatanhambatan, biasanya hambatan-hambatan itu ada pada beberapa hal misalnya pertama, kurangnya partisipasi guru dalam pengembangan kurikulum. Hal ini bisa disebabkan karena kurangnya waktu yang dimiliki oleh guru, kekurangsesuaian pendapat baik itu sesama guru maupun dengan kepala sekolah dan administraror. Kedua, hambatan yang datang dari masyarakat, untuk pengembangan kurikulum dibutuhkan dukungan masyarakat baik dalam pembiayaan maupun dalam memberikan umpan balik terhadap sistem pendidikan atau kurikulum yang sedang berjalan. Masyarakat merupakan input dari

34 Dede Supriyanto, Pengembangan Kurikulum Pendidikan Anak Berkebutuhan Khusus (Bandung: Kementerian Pendidikan dan Kebudayaan pada Pusat Pengembangan dan Pemberdayaan Pendidikan dan Tenaga Kependidikan Taman Kanak-kanak dan Pendidikan Luar Biasa, 2012), 16 102 | لurnal Auladuna 
Model Pengembangan Kurikulum Adaptif pada Madrasah Ibtidaiyah.... sekolah. Keberhasilan pendidikan, ketepatan kurikulum yang digunakan membutuhkan bantuan serta input fakta dan pemikiran dari masyarakat. Ketiga, hambatan lain yang sering dihadapi dalam pengembangan kurikulum adalah masalah biaya, karena dalam pengembangan kurikum apalagi yang berbentuk kegiatan eksperimen baik metode, isi atau sistem secara keseluruhan membutuhkan biaya yang tidak sedikit. ${ }^{35}$

Dalam pengembangan kurikum Madrasah Ibtidaiyah Inklusifpun akan banyak mengalami berbagai macam hambatan diantaranya:

1. Hambatan yang utama terletak pada kesiapan guru-guru di Madrasah, karena pada dasarnya memang bukanlah hal yang mudah bagi guru yang biasa mendidik anak-anak normal mendidik anak-anak berkebutuhan khusus hal ini memerlukan edukasi bagi para guru

2. Partisipasi orangtua atau masyarakat kepedulian mereka terhadap pendidikan anak berkeburtuhan khusus masih sangat rendah sehingga minim partisipasi dari orangtua peserta didik berkebutuhan khusus dan juga masyarakat sekitar.

3. Sarana dan prasarana Madrasah Ibtidaiyah yang kurang mendukung untuk pembelajaran anak berkebutuhan khusus,

Untuk itu harus ada upaya-upaya kerjasama dan saling bahu membahu antara yang satu dan lainnya, untuk menyelesaikan hambatan-hambatan tersebut, sehingga pengembangan kurikulum di madrasah Ibtidaiyah inklusif ini bisa berhasil diterapkan dengan baik dan menghasilkan output yang memuaskan masyarakat sekitarnya. Sehingga peran Madrasah sebagai salah satu lembaga yang berciri khas Islam ini dapat diakui dan diterima eksistensinya bagi semua kalangan peserta didik baik itu anak berkebutuhan maupun non berkebutuhan khusus.

\section{PENUTUP}

\section{Simpulan}

Eksistensi Pendidikan Inklusif di Madrasah Ibtidaiyah tentunya memberikan kesempatan pada anak-anak berkebutuhan khusus untuk mendapatkan pendidikan yang sama dengan anak normal lainnya. Oleh karena itu dibutuhkan kesiapan Madrasah

35 Nana Syaodih Sukmadinata, Pengembangan Kurikulum: Teori dan Praktek (Bandung: PT Remaja Rosdakarya, 2005), 160-161 
Ibtidaiyah untuk mendidik anak-anak berkebutuhan khusus tersebut dengan kurikulum yang sesuai dengan kebutuhan mereka, sehingga mereka tidak perlu lagi bersekolah di Sekolah Luar Biasa yang keberadaanya jauh dari tempat tinggalnya. Untuk itulah perlu adanya kerjasama antara pihak Madrasah dengan orangtua murid serta masyarakat untuk mewujudkan Madrasah Ibtidaiyah Inklusif yang berkualitas sehingga dapat membantu memberikan layanan pendidikan bagi anak berkebutuhan khusus dengan baik.

Selain itu keberadaan Madrasah Ibtidaiyah Inklusif ini dapat memberikan poin lebih terhadap anak berkebutuhan khusus, karena selain dibekali ilmu pengetahuan mereka juga dibekali dengan nilai-nilai ajaran Islam yang dapat menjadikan mereka pribadi yang berakhlak dan lebih religious. Sehingga anak-anak berkebutuhan khusus ini secara mental dan intelektual lebih siap dalam menghadapi persaingan hidup di masa depannya. 
Model Pengembangan Kurikulum Adaptif pada Madrasah Ibtidaiyah....

\section{DAFTAR PUSTAKA}

Budiyanto, dkk. Modul Pelatihan Pendidikan Inklusif. Jakarta: Kementerian Pendidikan Nasional, 2010.

Daulay, Haidar Putra. Sejarah Pertumbuhan dan Pembaharuan Pendidikan Islam Indonesia, Jakarta: Kencana Predana Media Group, 2009.

Dede Supriyanto. Pengembangan Kurikulum Pendidikan Anak Berkebutuhan Khusus. Bandung: Kementerian Pendidikan dan Kebudayaan (Pusat Pengembangan dan Pemberdayaan Pendidikan dan Tenaga Kependidikan Taman Kanak-kanak dan Pendidikan Luar Biasa).

Emawati. Mengenal Lebih Jauh Sekolah Inklusi. Pedagogik Jurnal Pendidikan Vol. 5 No. $1,2008$.

Hamalik, Oemar. Dasar-dasar Pengembangan Kurikulum. Bandung: PT Remaja Rosdakarya, 2007.

Rosdakarya, 2006.

Handani, Ihsan dan Fuad Ihsan. Filsafat Pendidikan Islam. Bandung: Pustaka Setia, 2001.

Indianto, R. Implementasi Pendidikan Inklusi. Surakarta: Universitas Sebelas Maret, 2013.

Ishartiwi. Implementasi Pendidikan Inklusif bagi Anak Berkebutuhan Khusus dalam Sistem Persekolahan Nasional. Jurnal Pendidikan Vol. 6 No. 2.

Lewy, Arief. Planning the School Curriculum. Terj. Winda Habimono. Jakarta: Bhratara Karya Aksara, 1983.

Muhaimin. Pengembangan Kurikulum Pendidikan Agama Islam: di Sekolah, Madrasah, dan Perguruan Tinggi. Jakarta: Raja Grafindo Persada, 2005.

Mumpuniarti. Pembelajaran Nilai Keberagaman dalam Pembentukan Karakter Siswa SD Inklusi. Jurnal Pendidikan Karakter. Yogyakarta: LPPMP UNY, 2011.

Nashir, Haedar. Pendidikan Karakter Berbasis Agama. Yogyakarta: Multi Presindo, 2013.

Nasution. Asas-asas Kurikulum. Jakarta: PT Bumi Aksara, 2001.

Nata, Abuddin. Filsafat Pendidikan Islam. Jakarta: Logos Wacana Ilmu, 1997.

Nolker, Helmut dan Eberhard Schoenfeldt. Berufsbildung, Unterricht, Curriculum, Planning. Terj. Agus Setiadi. Jakarta: PT. Gramedia, 1983.

Peraturan Menteri Agama Republik Indonesia No. 90 Th. 2013. 
Nur Jannah

Syarifatul Marwiyah

Peraturan Menteri Pendidikan Nasional Nomor 70 Tahun 2009 Tentang Pendidikan Inklusif bagi Peserta Didik yang Memiliki Kelainan dan Memiliki Potensi Kecerdasan dan/ atau Bakat Istimewa. Jakarta: Direktorat Jenderal Pendidikan Dasar.

Praptiningrum, N. Fenomena Penyelenggaraan Pendidikan Inklusif bagi Anak Berkebutuhan. Jurnal Pendidikan Khusus Vol. 7 No. 2, 2010.

S., Dyah. Pengkajian Pendidikan Inklusif bagi Anak Berkebutuhan Khusus pada Jenjang Pendidikan Dasar dan Menengah. Jakarta: Depdiknas, 2008.

Semiawan, Cony. Perspektif Pendidikan Anak Berbakat. Jakarta: Grasindo, 1997.

Smith, J. David. Inklusi, Sekolah Ramah untuk Semua. Terj. Denis. Bandung: Penerbit Nuansa, 2006.

Sukmadinata, Nana Syaodih. Pengembangan Kurikulum: Teori dan Praktek. Bandung: PT Remaja Rosdakarya, 2005.

Suyanto dan Mudjito. Masa Depan Pendidikan Inklusif. Jakarta: Kemendiknas, 2012.

Syafruddin, Nurdin. Guru Profesional dan Implementasi Kurikulum. Jakarta: Ciputat Pers, 2002.

Undang-undang Sistem Pendidikan Nasional Republik Indonesia No. 2 Th. 2003. Jakarta: Sinar Grafika.

Unesco. Pendidikan Kebutuhan Khusus. Terj. Susi Septaviana Rakhmawati. Oslo: Unifub Forlag Universitas Oslo, 2001.

106| Jurnal Auladuna 